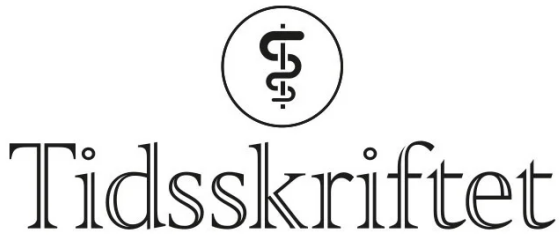

DEN NORSKE LEGEFORENING

\title{
Er surrogatendepunkt i kliniske studier nyttige?
}

RETTELSER

CECILIE DELPHIN AMDAL

KRISTIN BJORDAL

Tidsskr Nor Legeforen 2014; 134: 1128-9

I Tidsskriftet nr. 11/2014 s. 1129 er b og c i figur 2 blitt like. Riktig figur skal være: 


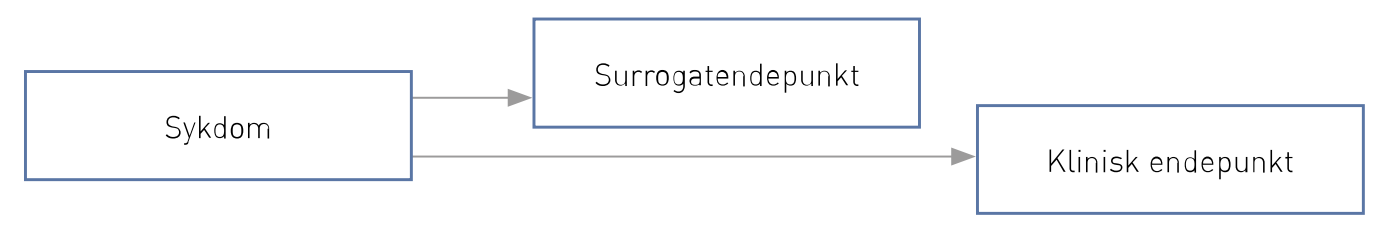

a.

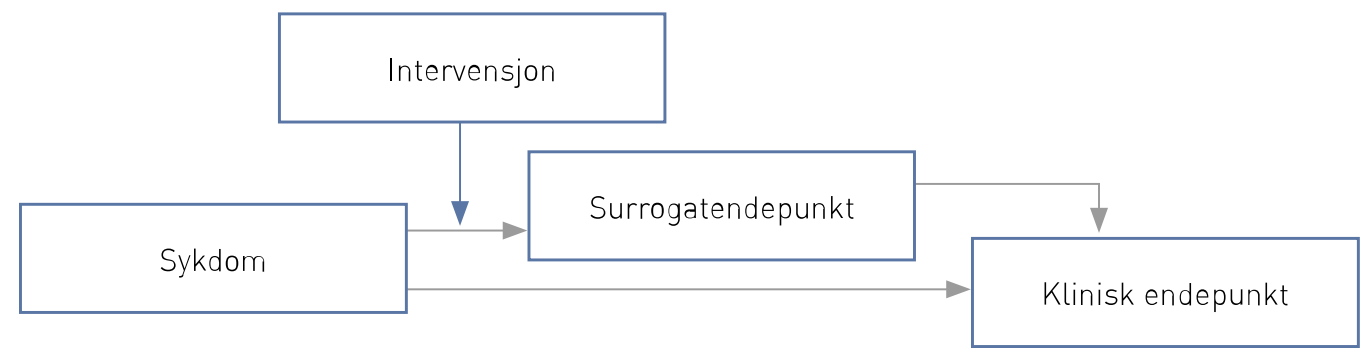

b.

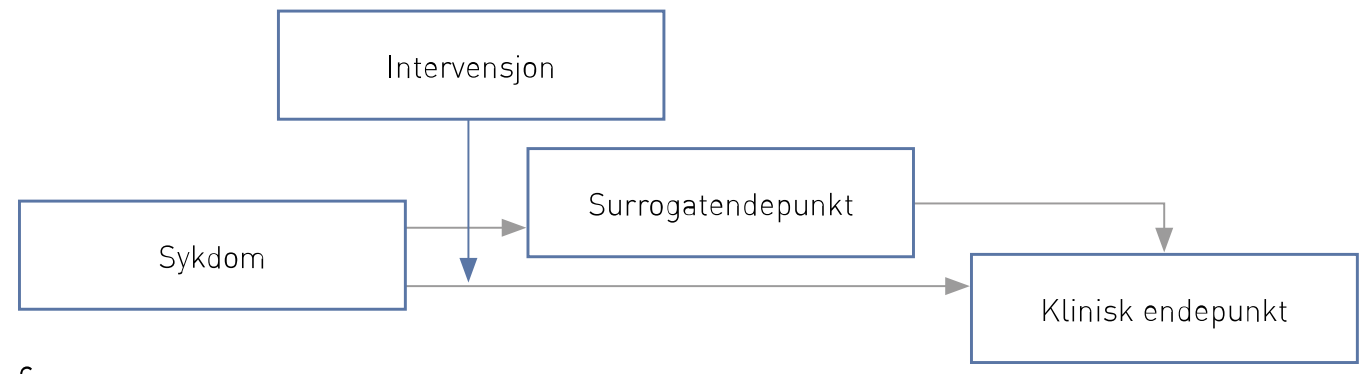

c.

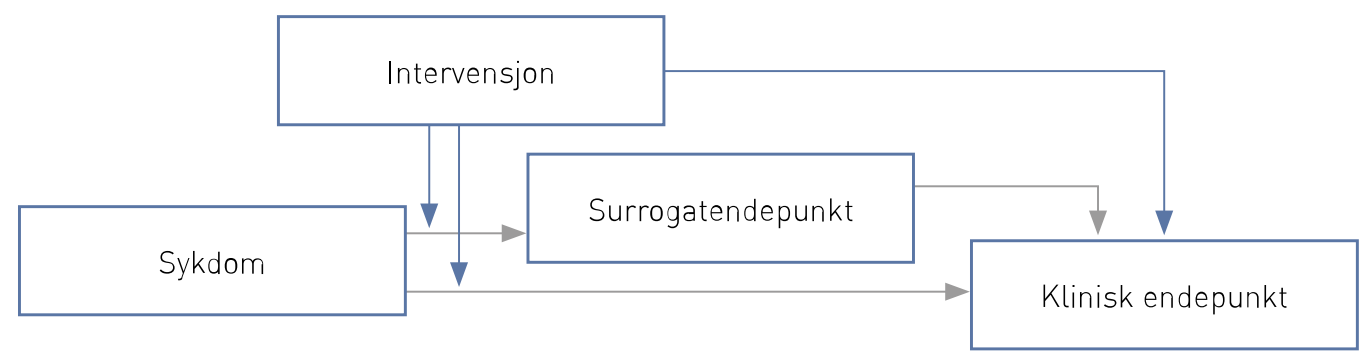

d.

Figur 2 Mulige grunner til at et surrogatendepunkt kan mislykkes (8). Selv om surrogatendepunktet er korrelert med det kliniske endepunktet er det ikke nødvendigvis slik at det involverer de samme patofysiologiske mekanismene. a) Sykdommens virkning på surrogatendepunktet og det kliniske endepunkt er uavhengig av hverandre, b) Sykdommen har flere virkningsmekanismer på det kliniske endepunktet og behandlingen virker på den veien som fanges opp av surrogatendepunktet. Dermed kan surrogatendepunktet fange opp effekt av behandlingen, men hva det betyr for det kliniske utfallet er usikkert, c) Behandlingen kan virke på en mekanisme som er uavhengig av surrogatendepunktet, d) Behandlingen kan ha annen og uønsket innvirkning på et pasientrelevant endepunkt enn gjennom surrogatendepunktet Vi beklager feilen. Den er rettet på nett.

Publisert: 2. september 2014. Tidsskr Nor Legeforen. DOI: 10.4045/tidsskr.14.0843

(C) Tidsskrift for Den norske legeforening 2023. Lastet ned fra tidsskriftet.no 26. april 2023. 